\title{
Malayo-Polynesian Language
}

National Cancer Institute

\section{Source}

National Cancer Institute. Malayo-Polynesian Language. NCI Thesaurus. Code C160953.

An Austronesian language spoken by the Austronesian people of the island nations of Southeast Asia and the Pacific Ocean, with a smaller number in continental Asia. 